\title{
Can mussels be used as sentinel organisms for characterization of pollution in urban water systems?
}

\author{
Elke S. Reichwaldt and Anas Ghadouani
}

Aquatic Ecology and Ecosystem Studies, School of Civil, Environmental and Mining Engineering, M015, The University of Western Australia, 35 Stirling Highway, Crawley, Western Australia 6009, Australia

Correspondence to: Elke S. Reichwaldt (elke.reichwaldt@uwa.edu.au)

Received: 4 December 2015 - Published in Hydrol. Earth Syst. Sci. Discuss.: 19 January 2016

Revised: 1 April 2016 - Accepted: 15 June 2016 - Published: 8 July 2016

\begin{abstract}
Urbanization strongly impacts aquatic ecosystems by decreasing water quality and altering water cycles. Today, much effort is put towards the restoration and conservation of urban waterbodies to enhance ecosystem service provision, leading to liveable and sustainable cities. To enable a sustainable management of waterbodies, the quantification of the temporal and spatial variability of pollution levels and biogeochemical processes is essential. Stable isotopes have widely been used to identify sources of pollution in ecosystems. For example, increased nitrogen levels in waterbodies are often accompanied with a higher nitrogen stable isotope signature $\left(\delta^{15} \mathrm{~N}\right)$, which can then be detected in higher trophic levels such as mussels. The main aim of this study was to assess the suitability of nitrogen stable isotopes as measured in mussels (Mytilus edulis), as an indicator able to resolve spatial and temporal variability of nitrogen pollution in an urban, tidally influenced estuary (Swan River estuary in Western Australia). Nitrogen concentrations were generally low and nitrogen stable isotope values of nitrate throughout the estuary were well within natural values of uncontaminated groundwater, organic nitrate from soils, or marinederived sources, indicating groundwater inflow rather than pollution by human activity was responsible for differences between sites. The $\delta^{15} \mathrm{~N}$ signature in mussels was very stable over time within each site which indicated that mussels can be used as time-integrated sentinel organisms in urban systems. In addition, our study shows that the nature of the relationship between $\delta^{15} \mathrm{~N}$ in the mussels and the nitrate in the water can provide insights into site-specific biogeochemical transformation of nutrients. We suggest that mussels and other sentinel organisms can become a robust tool for the detection and characterization of the dynamics of a number of
\end{abstract}

emerging anthropogenic pollutants of concern in urban water systems.

\section{Introduction}

Humans exert a growing impact on the environment supporting them. Today, more than $50 \%$ of the world's population is living in cities and this percentage is projected to further increase to up to $80 \%$ by 2050 (Pickett et al., 2011; United Nations, 2013). Impervious surfaces in cities lead to less rainfall infiltrating the soil. Instead, stormwater runoff is directly transported to waterbodies, polluting them with nutrients, heavy metals, and bacteria (Makepeace et al., 1995; Brezonik and Stadelmann, 2002). Urbanization has resulted in increased eutrophication of waterbodies leading to deteriorated ecosystems worldwide, reducing natural biodiversity and ecosystem services (Heathwaite, 2010). Environmental management is often hampered by a limited understanding of the temporal and spatial variability of pollution levels, the sources of contamination and the processes within systems that affect the recovery of a system (Kooistra et al., 2001; Scheffer et al., 2001; Lahr and Kooistra, 2010). In addition, the traditional hierarchical water management practices that are still in use around the world have been criticized as being ineffective and leaving little scope for adaptation to changes (Pahl-Wostl, 2007; van de Meene et al., 2011). The current trend to decentralize such urban water management might allow for more local management of water resources, indicating the need for improving our understanding of the variability of pollution levels in a range of urban waterbodies with greater emphasis on local processes. 
Many urban estuaries are highly impacted by human activity due to direct input of pollutants, such as nitrogen from urban, agriculture, and industry areas (e.g. Oczkowski et al., 2008), which can lead to eutrophication. In urban estuaries, tributaries often transport high amounts of nitrogen from the watershed into the estuary, causing water-quality problems including toxic bloom development (Hamilton, 2000; Atkins et al., 2001). Nitrogen concentration gradients might develop with higher upstream and lower downstream values, where nutrients are diluted by seawater (Dähnke et al., 2010; Fry et al., 2011). This can lead to a spatial variability of nitrogen concentration within estuaries. Nitrogen pollution can also be highly variable in time with higher nitrogen concentrations in estuaries found during times of high water input by tributaries. Smaller-scale variability in temporal and spatial nitrogen concentrations can additionally stem from local differences in hydrological processes (Linderfelt and Turner, 2001), variations in fertilizer use in agricultural areas or temporal failure of septic tank systems causing leakage of sewage, leading to localized places of concern for water management.

Anthropogenic nitrogen and organic pollution of water systems, including the interaction between surface and groundwater, have been successfully investigated using a range of stable isotopes (Sikdar and Sahu, 2009; Yang et al., 2012; Lutz et al., 2013). In addition, stable isotopes have been widely used in purely hydrological studies focused on flow paths, hydraulic residence time, and other hydrological dynamics (Clay et al., 2004; Rodgers et al., 2005; Volkmann and Weiler, 2014). Stable isotopes of nitrogen $(\mathrm{N})$, carbon $(\mathrm{C})$, sulfur $(\mathrm{S})$, and oxygen $(\mathrm{O})$ in water and biota have also been applied as an integrated measure of ecosystem processes (Robinson, 2001; Chaves et al., 2003; Pace et al., 2004). Furthermore, the analysis of the nitrogen signature has proven to be an especially powerful tool as an indicator of anthropogenic contamination (Lake et al., 2001; McKinney et al., 2002; Fry and Allen, 2003; Xu and Zhang, 2012) and land use (Harrington et al., 1998; Broderius, 2013; Carvalho et al., 2015), bearing on the fact that the sources of contamination such as animal manure, sewage, septic waste, and some fertilizers carry higher nitrogen signatures values and consequently a higher $\delta^{15} \mathrm{~N}$ (Heaton, 1986; Cabana and Rasmussen, 1996; Kellman, 2005; Choi et al., 2007). This signal is then passed on to higher trophic levels up the food chain (Cabana and Rasmussen, 1994; Carvalho et al., 2015): elevated $\delta^{15} \mathrm{~N}$ signals in nitrate have been shown to lead to elevated $\delta^{15} \mathrm{~N}$ signals in organisms that directly take up nitrate from the water, such as phytoplankton and microbes (Harrington et al., 1998). These organisms form an important part of particulate organic matter (POM), which serves as food for filter feeders (e.g. mussels). Mussels that ingest POM with an elevated $\delta^{15} \mathrm{~N}$ signal will then also show a higher $\delta^{15} \mathrm{~N}$ signal.

Assessing anthropogenic pollution of a system by directly measuring the isotopic signature of nitrogen containing nutri- ents (e.g. nitrate, ammonium) or of aquatic short-lived organisms with fast tissue turnover times, such as phytoplankton, may significantly under- or overestimate the average level of pollution, as the result strongly depends on the time of measurement. Bivalves, on the other hand, which include the blue mussel, are primary consumers with limited movement, and have been suggested as suitable site-specific bioindicators of time-averaged persistence of nutrient pollutants, because their isotopic signature fluctuates less than that of their food sources due to longer tissue turnover rates (Raikow and Hamilton, 2001; Post, 2002; Fukumori et al., 2008; Fertig et al., 2010; Wang et al., 2013). The blue mussel, Mytilus edulis, is a common sessile bivalve in estuarine and marine environments that is able to adapt to a wide range of environmental conditions, such as food concentration, temperature, and salinity (e.g. Thompson and Bayne, 1974; Widdows et al., 1979; Zandee et al., 1980; Almadavillela, 1984), and that shows low sensitivity to anthropogenic pressures (Mainwaring et al., 2014). As such, this species is able to thrive at different pollution levels and has therefore been used as an indicator species for pollution (Phillips, 1976) and as a model organism for physiological, genetic, and toxicological studies (Luedeking and Koehler, 2004) for some time. Earlier studies in polluted freshwater and marine systems found positive relationships between the concentration of nitrogen and the isotopic signature of nitrogen in mussels, and between the isotopic signature of nitrate- $\mathrm{N}$ and that of mussels (Cabana and Rasmussen, 1996; McClelland et al., 1997; Costanzo et al., 2001; Anderson and Cabana, 2005; Gustafson et al., 2007; Wen et al., 2010), suggesting that bivalves are suitable indicators of changes in the nutrient pollution load from agriculture and wastewater to waterbodies. However, very little information exists on the use of these stable isotopic signatures in urban systems.

The main aim of this study was to identify the variability of nitrogen concentration in an urban estuary over time and space and to ascertain the suitability of the isotopic signature $\left(\delta^{15} \mathrm{~N}\right)$ of blue mussel (Mytlius edulis) tissue as an indicator of nitrogen pollution in urban water systems. Specifically, we anticipated that (1) a higher input of nitrogen-rich waters upstream would lead to a higher isotopic signatures of nitrate, (2) spatial differences in the level of nitrates in the water would lead to spatial differences in mussel isotopic signature, and (3) the increased distance from the estuary mouth would lead to elevated ${ }^{15} \mathrm{~N}$ values in mussels due to elevated ${ }^{15} \mathrm{~N}$ inputs from nitrogen-rich waters upstream.

\section{Materials and methods}

\subsection{Study sites}

The study was performed in the lower reaches of the heavily urbanized Swan River estuary that flows through Perth, Western Australia (Fig. 1) (Atkins and Klemm, 1987). The 
catchment of this estuary is approximately $121000 \mathrm{~km}^{2}(\mathrm{Pe}-$ ters and Donohue, 2001) and encompasses urban, rural, agricultural and forested areas. In the urban area, drains contain areas with and without sewers (Peters and Donohue, 2001). The Swan River estuary experienced a major toxic cyanobacterial bloom in 2000, when a large rainfall event increased nutrient concentrations and decreased salinity within the estuary (Hamilton, 2000; Atkins et al., 2001), indicating that this estuary is prone to nutrient pollution from the watershed. The Swan River estuary is influenced by mostly diurnal tides with a mean tidal range at the mouth of the estuary of $0.8 \mathrm{~m}$. At the same time, the estuary is seasonally forced with a large discharge of freshwater from the tributaries during the wetter winter months (May-September), and little freshwater discharge during dry summers. This leads to fresh-to-brackish water in parts of the estuary in winter with a freshwater lens overlying saltwater, and an inland progression of the saltwater wedge, making the estuary a saltwater habitat during drier months (Stephens and Imberger, 1996). The Swan River estuary is permanently open to the ocean and has two major freshwater tributaries, the Swan River and the Canning River (Fig. 1). While there are also several short stormwater drains leading into the lower Swan River estuary that could potentially provide nutrient input into the Swan River estuary from the adjacent land; these drains did not flow during the study.

Seven sites within the lower Swan River estuary were sampled six times for blue mussels and nine times for nutrients, particulate organic matter, chlorophyll $a$, temperature, salinity, $\mathrm{pH}$, and oxygen during the wetter season (AprilNovember 2010). The sites were jetties at Point Walter (WP) $\left(32^{\circ} 0^{\prime} 39.23^{\prime \prime} \mathrm{S}, 115^{\circ} 47^{\prime} 15.11^{\prime \prime} \mathrm{E}\right)$, Minim Cove Park (MC) $\left(32^{\circ} 1^{\prime} 21.23^{\prime \prime} \mathrm{S}, 115^{\circ} 45^{\prime} 57.38^{\prime \prime} \mathrm{E}\right)$, Swan River Canoe Club (SCC) $\left(32^{\circ} 0^{\prime} 27.31^{\prime \prime} \mathrm{S}, 115^{\circ} 46^{\prime} 18.73^{\prime \prime} \mathrm{E}\right)$, Claremont $(\mathrm{Cl})\left(31^{\circ} 59^{\prime} 23.80^{\prime \prime} \mathrm{S}, 115^{\circ} 46^{\prime} 52.97^{\prime \prime} \mathrm{E}\right)$, Broadway (BRD) $\left(31^{\circ} 59^{\prime} 25.55^{\prime \prime} \mathrm{S}, 115^{\circ} 49^{\prime} 5.49^{\prime \prime} \mathrm{E}\right)$, Applecross (AC) $\left(32^{\circ} 0^{\prime \prime} 17.59^{\prime \prime} \mathrm{S}, 115^{\circ} 49^{\prime} 58.29^{\prime \prime} \mathrm{E}\right)$, and Como Beach (CB) $\left(31^{\circ} 59^{\prime \prime} 37.46^{\prime \prime} \mathrm{S}, 115^{\circ} 51^{\prime} 10.33^{\prime \prime} \mathrm{E}\right)$ (Fig. 1). While MC and SCC are situated at the deeper part of the estuary (depth $<17 \mathrm{~m}$ ), all other sites are located in the shallower part (depth $<10 \mathrm{~m}$ ) (Stephens and Imberger, 1996). The jetty at $\mathrm{Cl}$ is situated in a shallow bay (depth approximately $2 \mathrm{~m}$ ) with established seagrass meadows and abundant macroalgae and macrophytes (Department of Water, 2010). Additionally, a one-time marine reference measurement was performed towards the end of the study outside the estuary at Woodman Point Jetty (WO; $32^{\circ} 7^{\prime} 26.97^{\prime \prime} \mathrm{S}, 115^{\circ} 45^{\prime} 32.10^{\prime \prime}$ E) (Fig. 1).

\subsection{Sampling and analyses}

On each date, sampling was performed $0.5-1 \mathrm{~h}$ prior to high and low tide at each site, respectively. While mussels were sampled only once per day, all other parameters were sampled at high and low tide. Salinity, $\mathrm{pH}$, water temperature, and oxygen were measured at $20 \mathrm{~cm}$ depth with hand-held probes (WP-81; TPS-DO 2 ). At each site, water samples for

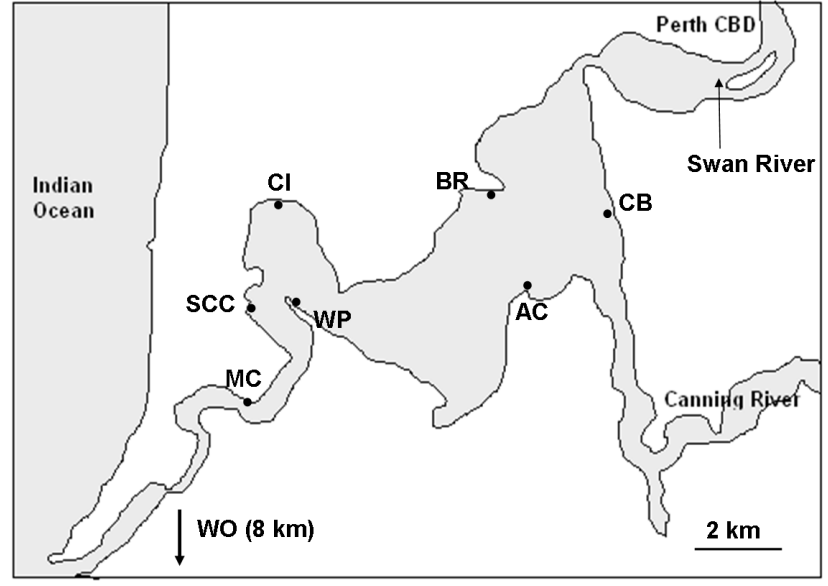

Figure 1. Map indicating the seven sampling sites (jetties) within the lower Swan River estuary, Perth, Western Australia. AC: Applecross, BRD: Broadway, CB: Como Beach, Cl: Claremont (Freshwater Bay), MC: Minim Cove, SCC: Swan River Canoe Club, WP: Point Walter; the ocean reference site was located $8 \mathrm{~km}$ south of the estuary mouth (WO: Woodman Jetty).

quantification of nutrient concentration (TP is total phosphorous; $\mathrm{NO}_{x}$ is nitrate $\left(\mathrm{NO}_{3}\right)$ plus nitrite $\left(\mathrm{NO}_{2}\right) ; \mathrm{NH}_{4}^{+}$is ammonium), phytoplankton biomass (as chlorophyll $a$ ), and stable isotope analysis of $\mathrm{NO}_{3}\left(\delta^{15} \mathrm{~N}, \delta^{18} \mathrm{O}\right)$ and particulate organic matter (POM; $\delta^{15} \mathrm{~N}$ ) were taken from 10 to $20 \mathrm{~cm}$ below the surface and brought back to the laboratory in glass bottles that were stored on ice. Nine blue mussels per site were randomly taken from the pylons of the jetties at each site from between 20 and $40 \mathrm{~cm}$ depth and brought into the laboratory on ice in bags containing water from the respective site. There were no mussels at WP in November.

In the laboratory, total phytoplankton concentration at each site was measured with a bench top version of the FluoroProbe (bbe Moldaenke, Germany) as $\mu \mathrm{g}$ chl $a \mathrm{~L}^{-1}$ (Beutler et al., 2002; Ghadouani and Smith, 2005). Water for quantification of $\mathrm{NO}_{x}(\mathrm{LOQ}=0.14 \mu \mathrm{M})$ and $\mathrm{NH}_{4}^{+}(\mathrm{LOQ}$ $=0.21 \mu \mathrm{M})$ concentrations was filtered through $0.45 \mu \mathrm{m}$ syringe filters (Ht Tuffryn, Pall, Australia) and kept frozen until analysis at the Marine and Freshwater Research Laboratory (Murdoch University, Western Australia) using a Lachat QuikChem Flow Injection Analyser. Water for analysis of nitrate $\delta^{15} \mathrm{~N}$ and $\delta^{18} \mathrm{O}$ was filtered through $0.2 \mu \mathrm{m}$ syringe filters (Ht Tuffryn, Pall, Australia) and kept frozen until analysis at the UC Davis Stable Isotope Facility (Davis, California, USA) using a ThermoFinnigan GasBench plus PreCon trace gas concentration system interfaced to a ThermoScientific Delta V Plus isotope-ratio mass spectrometer (Bremen, Germany), with the bacteria denitrification method (Sigman et al., 2001). All values are reported in per mill (\%o) with respect to the international standards $\left(\delta^{15} \mathrm{~N}\right.$ : air; $\delta^{18} \mathrm{O}$ : Vienna Standard Mean Ocean Water, VSMOW). The limit of quantification for this analysis was $0.71 \mu \mathrm{M} \mathrm{NO}_{3}-\mathrm{N}$ and the exter- 
nal errors of analysis were $0.4 \%$ for nitrate $\delta^{15} \mathrm{~N}$ and $0.8 \%$ o for nitrate $\delta^{18} \mathrm{O}$. Raw water was used for quantification of TP with the ascorbic acid method (APHA, 1998).

To determine the isotopic composition of nitrogen in particulate organic matter (POM), which is the food source for mussels that presents the direct link between nitrate and the mussels, $0.7-2.5 \mathrm{~L}$ of water was filtered onto pre-combusted $25 \mathrm{~mm}$ GF/C filters (Whatman), which were then dried for $24 \mathrm{~h}$ at $60^{\circ} \mathrm{C}$ and stored in a desiccator until analysis. Harvested mussels were measured and dissected to obtain the foot tissue for stable isotope analysis. The feet of three individuals per site were combined, dried at $60^{\circ} \mathrm{C}$ for at least $24 \mathrm{~h}$, fully homogenized with mortar/pestle, and stored in a desiccator until a subsample was analysed for mussel $\delta^{15} \mathrm{~N}$ and $\mathrm{C}: \mathrm{N}$ ratio. As nine mussels per site were collected, this resulted in three replicates for stable isotope analysis per site, with each replicate comprised of the feet of three mussels. This method was adopted from Lancaster and Waldron (2001), as the minimum detectable difference between two populations was negatively associated with the number of replicate samples and the number of individual animals combined in each replicate. Therefore, this method is preferred when only small differences in the stable isotope signatures are expected. We used foot tissue for the analysis, because it is easy to identify and obtain, and because its $\delta^{15} \mathrm{~N}$ value presents a time-averaged value of $\delta^{15} \mathrm{~N}$ of the food source. Stable isotope analysis of mussel feet tissue and POM was performed at the West Australian Biogeochemistry Centre (University of Western Australia, Australia) with a continuous flow Delta V Plus mass spectrometer (connected with a Thermo Flush 1112 via Conflo IV) (ThermoFinnigan, Germany). All values are reported in per mill $(\% o)$ with respect to the international standard (air). The external errors of analysis were $0.10 \%$ ofor $\delta^{15} \mathrm{~N}$. To check whether the size of mussels was correlated with their $\delta^{15} \mathrm{~N}, 13$ mussels with shell lengths between 30 and $54 \mathrm{~mm}$ were sampled from $\mathrm{MC}$ in July.

\subsection{Data processing and statistical analyses}

Relationships between parameters (i.e. nutrient concentrations, physical parameters, chlorophyll $a$, stable isotope values), and distance to the estuary mouth were analysed with linear regressions. Differences between sites were analysed with one-way ANOVA or Kruskal-Wallis one-way ANOVA, in cases where the normality test failed (Sokal and Rohlf, 1995). If significant, the parametric Tukey (equal variances) or the non-parametric Games-Howell (non-equal variances) post hoc tests were used to identify which sites were different. The Mann-Whitney $U$ test was used to compare chlorophyll $a$ concentrations between high and low tide. All analyses were done with IBM ${ }^{\circledR}$ SPSS $^{\circledR}$ Statistics 20 or Sigma Plot ${ }^{\circledR}$ Statistics 11.0, and significance level was set to $P<0.05$ unless stated otherwise.

\section{Results}

\subsection{Physicochemical parameters}

Rainfall was below average in 2010, with $421 \mathrm{~mm}$ for the entire sampling period, while the average for this period was $690 \mathrm{~mm}$ in the previous 17 years (1993-2009; Bureau of Meteorology, 2016). This resulted in a lower-than-usual discharge from the tributaries into the estuary with a mean discharge from the Swan River of $7.5 \times 10^{5} \mathrm{~m}^{3} \mathrm{~d}^{-1}$ in 2010 compared to an average discharge of $8.4 \times 10^{6} \mathrm{~m}^{3} \mathrm{~d}^{-1}$ for the period of 1993-2009 for the same season (min-max: $1.99 \times$ $10^{6} \mathrm{~m}^{3} \mathrm{~d}^{-1}(2002)-2.21 \times 10^{7} \mathrm{~m}^{3} \mathrm{~d}^{-1}$ (1996) (Department of Water, 2016)). This might have contributed to higher salinities throughout the entire estuary during this study than previously reported (Stephens and Imberger, 1997) and no relationship between salinity and distance to the estuary mouth was detected. During high tide, the salinity at all sites was between 24.2 and 32.4 and there was no difference in salinity between sites which can be considered brackish to saline (salinity of seawater is 35). Although salinity was not different between sites at low tide either, sites further away from the ocean (AC, CB, BRD) were entirely freshwater between April and June, while saline (mean \pm SE; $27.4 \pm 0.4$ ) conditions prevailed at all sites between July and November. There were no differences between sites in temperature (temporal range $12.5-23^{\circ} \mathrm{C}$; Kruskal-Wallis $H=0.584$, df $=6$ ), dissolved oxygen (temporal range $6.4-11.6 \mathrm{mg} \mathrm{L}^{-1}$, one-way ANOVA $F_{6,84}=0.764 ; 63-124 \%$ sat., one-way ANOVA $F_{6,84}=0.515$ ), and $\mathrm{pH}$ (temporal range 6.7-8.4; one-way ANOVA $F_{6,112}=0.163$ ). Total chlorophyll $a$ concentration was between 1.4 and $9.5 \mu \mathrm{gL}^{-1}$ with a mean of $3.9 \mu \mathrm{g} \mathrm{L}^{-1}$ (coefficient of variation $=0.18$ ). Total chlorophyll $a$ concentration was similar between sites (ANOVA; $F_{6,70}=1.45$ ), and did not differ between low and high tide at any site (Mann-Whitney $U$ test).

\subsection{Nutrient concentrations}

Overall, $\mathrm{NO}_{x}$ and $\mathrm{NH}_{4}^{+}$concentrations were low in the Swan River estuary. The concentration of $\mathrm{NO}_{x}$ ranged between below quantifiable limits ( $\mathrm{LOQ}=0.14 \mu \mathrm{M})$ and $15.0 \mu \mathrm{M}$ (median 0.29 ; mean \pm SD $0.72 \pm 1.7$ ), and differed significantly between sites (Kruskal-Wallis one-way ANOVA, $H=50.03$, $\mathrm{df}=6$ ) (Fig. 2). The concentration of $\mathrm{NH}_{4}^{+}$ ranged between the limit of quantification $(\mathrm{LOQ}=0.21 \mu \mathrm{M})$ and $2.6 \mu \mathrm{M}$ (median 0.78; mean $\pm \mathrm{SD}=0.85 \pm 0.58$ ) and did not differ between sites (Kruskal-Wallis one-way ANOVA, $H=7.9$, df =6). On average, $\mathrm{NO}_{x}$ was the dominant $\mathrm{N}$ source at $\mathrm{MC}, \mathrm{SCC}$, and $\mathrm{WO}$, while nitrogen from $\mathrm{NH}_{4}^{+}$was greater at all other sites (Fig. 2) (Kruskal-Wallis one-way ANOVA, $H=59.0$, df $=6$ ). Total phosphorous was below or just above the limit of quantification (LOQ $=0.32 \mu \mathrm{M}$ ) throughout the study and did not show any spatial or temporal trend. 


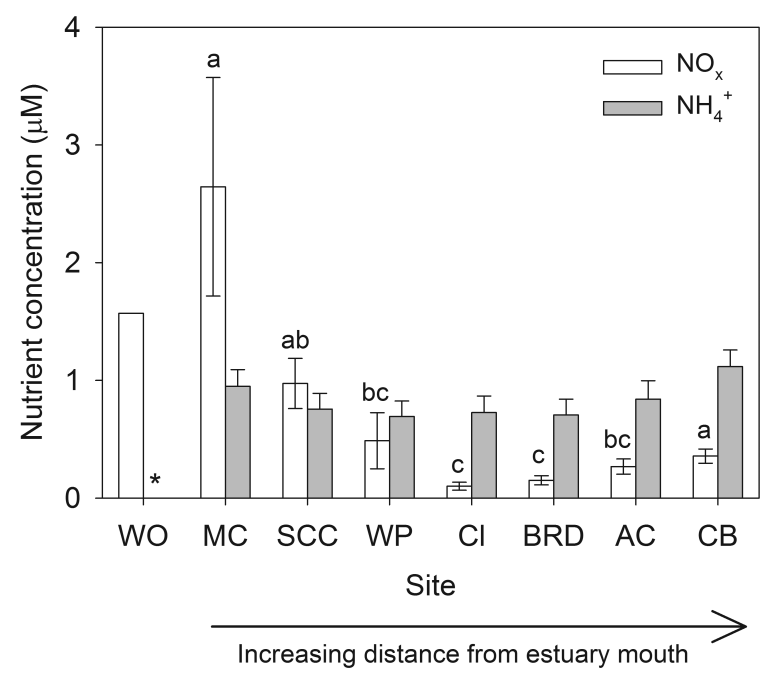

Figure 2. Mean concentration of $\mathrm{NO}_{x}$ and $\mathrm{NH}_{4}^{+}(\mu \mathrm{M})$ at each site. Letters indicate differences between sites for $\mathrm{NO}_{x}$ concentrations, with sites sharing the same letter being not significantly different. Error bars represent one standard error $(N=17)$. Asterisk at WO indicates that mean value of $\mathrm{NH}_{4}$ was below the limit of quantification.

The concentrations of total dissolved inorganic nitrogen $\left(\mathrm{TDIN}=\mathrm{NO}_{x}+\mathrm{NH}_{4}\right)(\mu \mathrm{M})$ and $\mathrm{NO}_{x}(\mu \mathrm{M})$ were higher towards the estuary mouth (Fig. 2), although these relationships were weak (TDIN: $r^{2}=0.113, y=-0.186 x+$ $3.69, F_{1,117}=14.86 ; \mathrm{NO}_{x}: r^{2}=0.153, y=-0.196 x+2.98$, $\left.F_{1,117}=21.16\right)$ and were driven by site MC only. Ammonium concentrations were not correlated with the distance from the estuary mouth $\left(F_{1,117}=0.41\right)$.

The TN:TP ratio (weight) of particulate organic matter was between 0 and 6.5 with $84 \%$ of the samples being below 2.2 in our study, indicating a high possibility of nitrogen limitation in this system (Redfield, 1958; Geider and La Roche, 2002).

\subsection{Stable isotope values of $\mathrm{NO}_{3}$}

Analysis of the stable isotope composition of $\mathrm{NO}_{3}$ was limited to a total of 25 samples that fulfilled nutrient concentration requirements for the analysis $\left(0.71 \mu \mathrm{MNO}_{3}-\mathrm{N}\right)$. Of these, 9 were from MC, 10 from SCC, 2 from AC, 3 from $\mathrm{CB}$, and 1 from WP. Nitrate $\delta^{15} \mathrm{~N}$ values varied between -1.3 and $10.4 \%$, while nitrate $\delta^{18} \mathrm{O}$ values ranged between 18.4 and $72.9 \%$. Nitrate $\delta^{15} \mathrm{~N}$ increased exponentially with increasing $\mathrm{NO}_{x}$ concentration $\left(F_{1,23}=10.50\right)$ (Fig. 3$)$ and differed between sites (one-way ANOVA; $F_{4,25}=5.94$ ). A post hoc test (Games-Howell) indicated that nitrate at MC was ${ }^{15} \mathrm{~N}$ enriched (mean $\left.\pm \mathrm{SD} ; 7.92 \% \circ \pm 2.55 ; n=12\right)$ compared to SCC $(2.71 \% \circ \pm 1.02 ; n=10)$ and $\mathrm{AC}(-0.19 \% \circ \pm 1.51$; $n=2)$. There was no temporal trend in nitrate $\delta^{15} \mathrm{~N}$ at sites $\mathrm{MC}$ and SCC, respectively, which were the only two sites for which sufficient data for such an analysis were available.

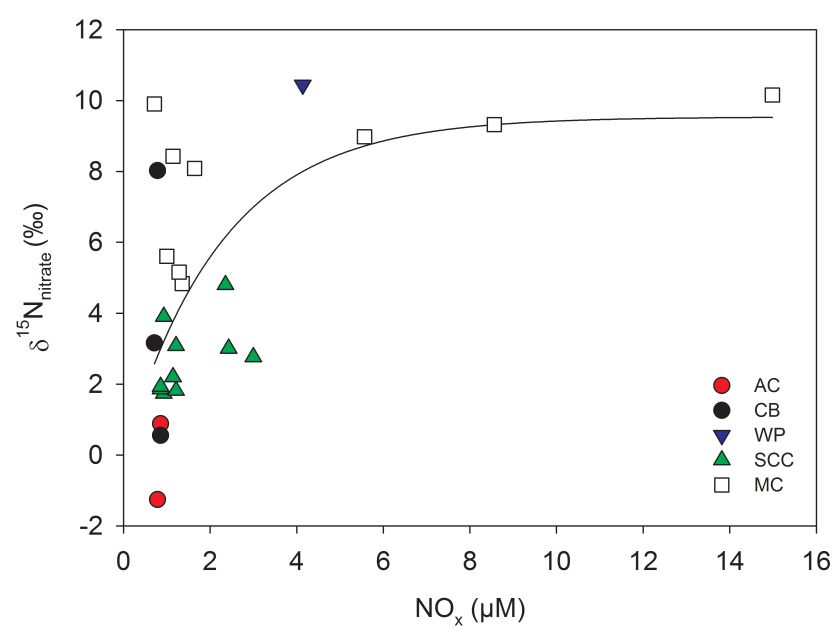

Figure 3. Relationship between nitrate $\delta^{15} \mathrm{~N}(\% \circ)$ and the concentration of $\mathrm{NO}_{x}(\mu \mathrm{M})\left(r^{2}=0.313, y=9.54\left(1-e^{-0.44 \mathrm{x}}\right), P<0.05\right)$.

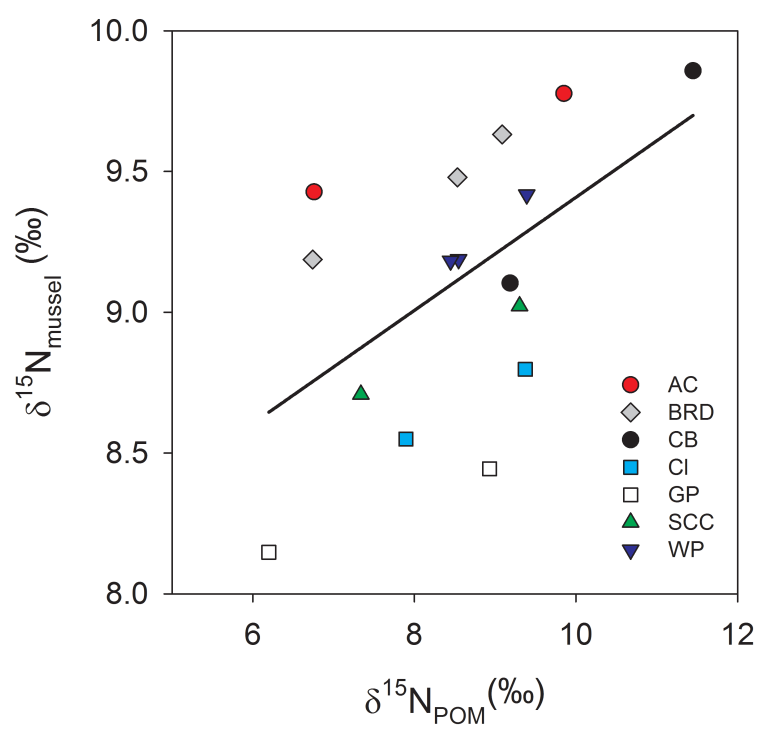

Figure 4. Relationship between mean $\delta^{15} \mathrm{~N}$ of POM and mussel $(\%)$. Linear regression is calculated using all data points $\left(r^{2}=\right.$ 0.303, $\left.y=0.20 \mathrm{x}+7.40, F_{1,14}=6.08, P<0.05\right)$.

Nitrate $\delta^{18} \mathrm{O}$ was not significantly different between sites $\left(F_{4,25}=0.059\right)$.

\subsection{Particulate organic matter (POM) $\delta^{15} \mathrm{~N}$ values}

POM $\delta^{15} \mathrm{~N}$ values were between 6.2 and $9.9 \%$ with no significant difference between sites $\left(F_{6,25}=1.327\right)$. A weak but significant negative relationship between POM $\delta^{15} \mathrm{~N}$ values and TDIN concentration was detected $\left(r^{2}=\right.$ $\left.0.163, y=-0.044 \mathrm{x}+9.37, F_{1,28}=5.44\right)$, while a significant positive relationship between nitrogen stable isotope signatures of POM and mussels was found $\left(r^{2}=0.303\right.$, $\left.y=0.20 \mathrm{x}+7.40, F_{1,14}=6.08\right)($ Fig. 4$)$. The relationship be- 


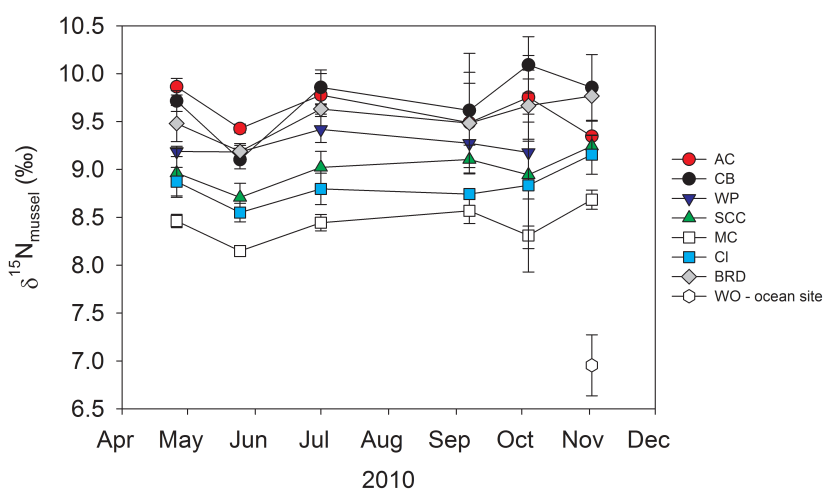

Figure 5. Mean $\delta^{15} \mathrm{~N}$ mussel signature (\%o) at each site over time. Error bars represent standard deviations of $N=3$ for April-July and WO, and $N=2$ for September-November 2010.

tween $\delta^{15} \mathrm{~N}$ of POM and nitrate was not significant; however, as this calculation was based on only five data points where simultaneous measurements of the two $\delta^{15} \mathrm{~N}$ values were available, the value of this result is uncertain.

\subsection{Mussel $\delta^{15} \mathrm{~N}$ values}

Values of $\delta^{15} \mathrm{~N}$ of mussels varied between 6.8 and $10.3 \%$ and the range was therefore smaller than the range seen in nitrate $\delta^{15} \mathrm{~N}(-1.3$ and $10.4 \%$ ). No significant relationship between mussel length and mussel $\delta^{15} \mathrm{~N}$ (linear regression; $\left.F_{1,13}=2.235\right)$ and no temporal trend in mussel $\delta^{15} \mathrm{~N}$ was detected (Fig. 5). Mussel $\delta^{15} \mathrm{~N}$ was significantly different between sites (one-way ANOVA; $\delta^{15} \mathrm{~N}: F_{6,98}=42.53$ ) and was negatively correlated with the concentration of total dissolved inorganic nitrogen $\left(r^{2}=0.486, F_{1,5}=4.73, P<0.1\right)$ (Fig. 6). When site $\mathrm{Cl}$ was omitted, the strength of the relationship increased $\left(r^{2}=0.838, F_{1,4}=20.69, P<0.05\right)$, while the relationship was not significant with an $r^{2}$ of 0.009 only when site MC was omitted (Fig. 6). Mussel $\delta^{15} \mathrm{~N}$ increased significantly with distance from the estuary mouth $\left(r^{2}=0.563, y=0.12 \mathrm{x}+7.74, F_{1,110}=141.65\right)($ Fig. 7) and showed a significant negative relationship between the $\delta^{15} \mathrm{~N}$ values of mussel and nitrate $\left(r^{2}=0.711, F_{2,10}=24.65\right)$ (Fig. 8).

\section{Discussion}

Urban development poses a major threat to aquatic ecosystems, resulting in a range of systems with different impact levels. The management of these waterbodies, whether they are historical, hybrid, or novel (Hobbs et al., 2014), requires a detailed knowledge of the complex interactions of processes in these systems. The limited understanding of spatial and temporal variabilities of pollutants is often the major limitation to successful and long-lasting restoration and protection efforts (Kooistra et al., 2001; Lahr and Kooistra, 2010). As

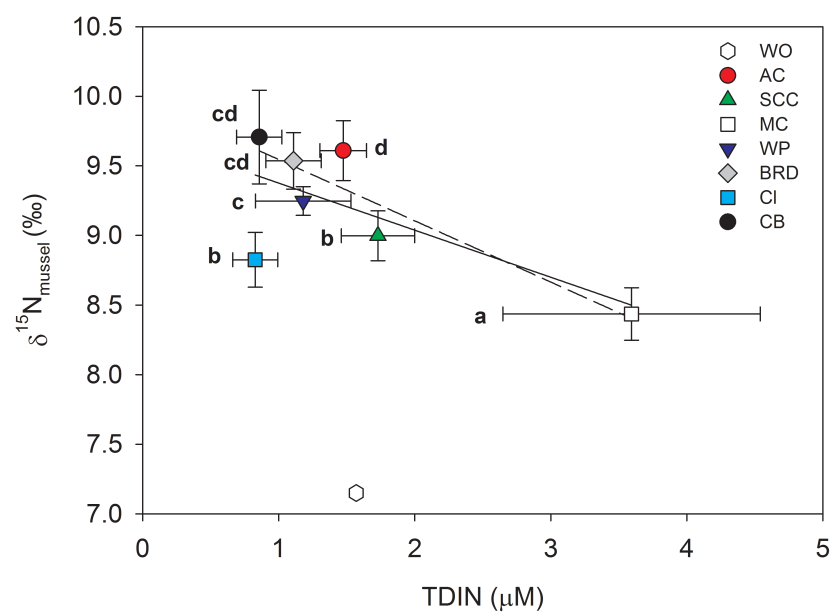

Figure 6. Relationship between mean mussel $\delta^{15} \mathrm{~N}(\% o)$ and total dissolved inorganic nitrogen (TDIN) $(\mu \mathrm{M})$. Error bars represent standard deviation for mussels $(N=6$ for all sites except for WP where $N=5$ ) and standard error of for TDIN $(n=17)$. The solid line represents the relationship calculated for all sites $\left(r^{2}=0.486, y=-0.338 \mathrm{x}+9.71\right)$, the dashed line when site $\mathrm{Cl}$ is omitted $\left(r^{2}=0.838, y=-0.440 \mathrm{x}+9.98\right)$. Letters indicate differences in $\delta^{15} \mathrm{~N}_{\text {mussels }}$ (ANOVA with Games-Howell post hoc test), with sites sharing the same letter being not significantly different. WO was not included in the regressions.

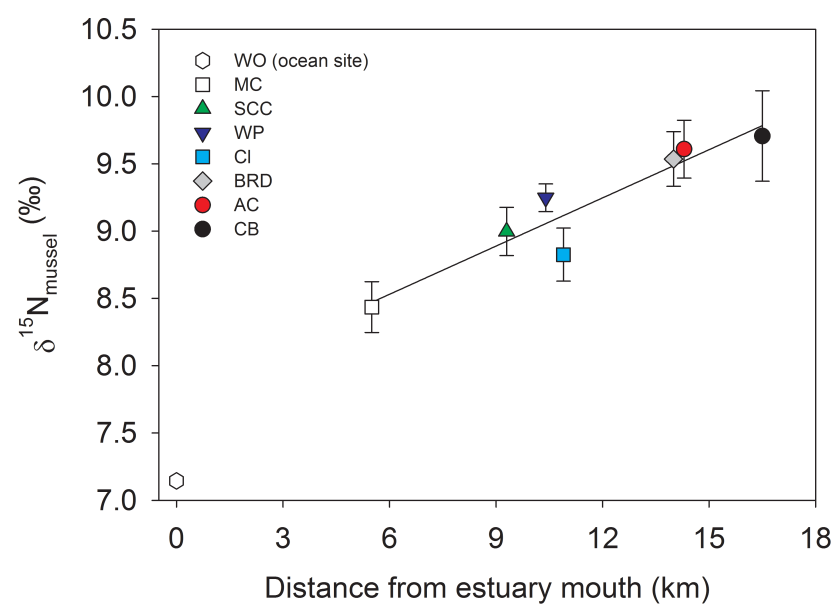

Figure 7. Relationship between mean $\delta^{15} \mathrm{~N}$ of mussels (\%o) and distance of sites from estuary mouth $\left(r^{2}=0.563, y=0.12 \mathrm{x}+7.74\right)$. Error bars represent standard deviation of $N=6$ for all sites except for WP where $N=5$.

such, it is essential to develop in-depth knowledge of local processes and pollution levels that will allow a decentralized management approach adapted to local issues (van de Meene et al., 2011).

Our study supports this notion by showing that the concentration of nitrates and the nitrogen stable isotope signatures of nitrate and of mussels were different between sites in the Swan River estuary. Site-specific differences in nutrient 


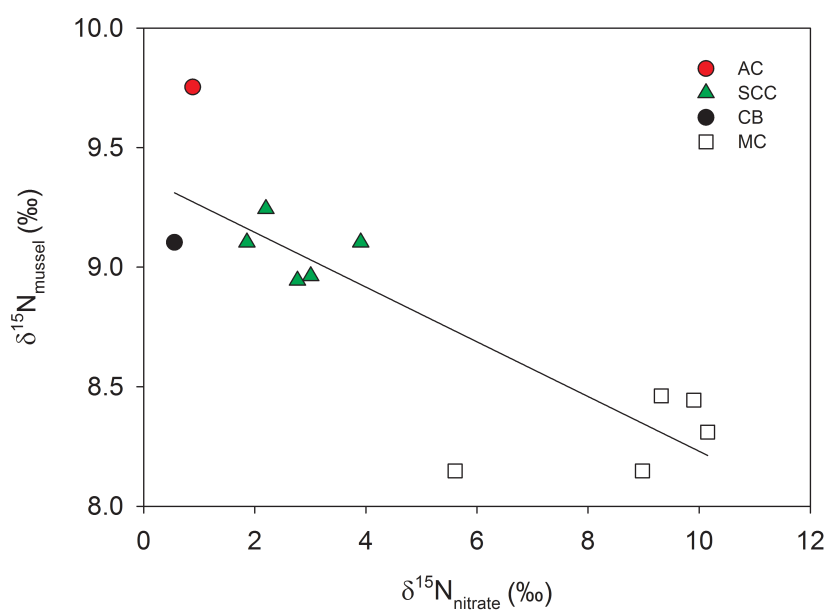

Figure 8. Relationship between nitrogen stable isotope signature of mussel and nitrate in the water $\left(r^{2}=0.711, y=-0.114 \mathrm{x}+9.37\right)$.

concentrations can be caused by local input of nutrients or by spatial differences in nutrient cycling caused by physicochemical conditions or biological factors (Michener and Lajtha, 2007). Additionally, nutrient input from the watershed often leads to higher nutrient concentrations upstream. During our study, freshwater input into the estuary was weak, leading to the estuary being mainly influenced by ocean water. This might have been the reason that nutrient concentrations did not increase upstream in our study and that nitrogen concentrations were low in general, leading to the conclusion that the Swan River estuary does not represent a highly impacted urban estuary. However, differences in $\mathrm{NO}_{x}$ and TDIN concentrations between sites suggested a significant site-specific input of nutrients into the Swan River estuary. This is supported by the fact that mean nitrogen concentrations at the site closest to the ocean (MC) were higher than the concentrations in the ocean (WO), pointing towards a local input of non-marine $\mathrm{NO}_{x}$ at MC.

Earlier studies indicated that the nitrogen stable isotope ratio of dissolved inorganic nitrogen was often higher at sites with high anthropogenic nitrogen pollution (Heaton, 1986; Cabana and Rasmussen, 1996). In the Swan River estuary, $\mathrm{NO}_{3}$ was enriched and there was a positive relationship between nitrate $\delta^{15} \mathrm{~N}$ and the concentration of $\mathrm{NO}_{x}$ throughout the estuary, although this was strongly driven by site MC. Because the isotopic signatures of nitrates were well in the range of values reported for surface water (ca. -4 to $+9 \%$; Xue et al., 2009), uncontaminated groundwater (ca. -1 to $+8 \%$; Xue et al., 2009), organic nitrate from soils (0 to $+10 \%$; Heaton, 1986), pristine streams (+1.8 to $+2.2 \%$; Harrington et al., 1998), or naturally available marine-derived dissolved inorganic nitrogen (ca. 6-8\%; Dudley and Shima, 2010), our study does not suggest differences in the level of human impact between sites. Additionally, nitrate $\delta^{18} \mathrm{O}$ values in our study are similar to values in- dicative of the atmospheric source $(+20$ to $+80 \%$; Kendall, 1998; Xue et al., 2009), suggesting that the higher concentration and enriched signature of $\mathrm{NO}_{x}$ at site $\mathrm{MC}$ is unlikely to result from anthropogenic pollution, but might rather be due to addition of $\mathrm{NO}_{x}$ by groundwater inflow, potentially in combination with different productivity or biochemical processes at this site compared to any of the other sites. Overall, results from the stable isotope analysis in combination with nitrogen concentrations indicate that anthropogenic nutrient pollution in the Swan River estuary is low.

The fraction of $\mathrm{NO}_{x}$ of the TDIN pool (\%) was significantly different between sites (data not shown; $\left.y=0.15 x-6.9, r^{2}=0.215, F_{1,23}=6.30, P<0.05\right)$, with site MC having a higher mean fraction $($ mean $=62.5 \%$ ) compared to all other sites, except for SCC. An earlier study by Sugimoto et al. (2009) also found a positive relationship between nitrate $\delta^{15} \mathrm{~N}$ values and the nitrate fraction in TDIN, which they explained by in situ isotopic effects during nitrification. However, whether higher $\delta^{15} \mathrm{~N}$ values of nitrate at $\mathrm{MC}$ are related to site-specific nitrification rates in our estuary needs further investigation, as the $\delta^{18} \mathrm{O}$ and $\delta^{15} \mathrm{~N}$ values of nitrate are rather representative of atmospheric $\mathrm{NO}_{3}$ deposition values (Durka et al., 1994; Fang et al., 2011) and nitrification is likely to play a minor role at ammonium concentrations $<5 \mu \mathrm{M}$ (Day et al., 1989) that prevail in the Swan River estuary.

Earlier studies found that nitrogen $\delta^{15} \mathrm{~N}$ values are reflected in higher trophic levels in a predictable way, with a positive relationship between $\delta^{15} \mathrm{~N}$ of nitrate, primary producer and primary consumer (e.g. mussels) (Cabana et al., 1994; Cabana and Rasmussen, 1996; Harrington et al., 1998; Oczkowski et al., 2008; Carvalho et al., 2015). In addition and identical to our study, the range of $\delta^{15} \mathrm{~N}$ values for nitrate and POM has been shown to be wider than the range for primary producers, indicating a timeaveraging effect in mussels (Gustafson et al., 2007; Wang et al., 2013). Previous studies reported mussel $\delta^{15} \mathrm{~N}$ values between +6.6 and $+16.7 \%$ in densely populated areas (Cabana and Rasmussen, 1996), polluted inland waterbodies (Wen et al., 2010; Wang et al., 2013), and a eutrophic estuary (Fry et al., 2011). Our values are at the lower end of this range, with mussel $\delta^{15} \mathrm{~N}$ values in our study being between 6.8 and $10.3 \%$, indicating the estuary is not highly polluted by wastewater, agriculture or fertilizers. We also found a positive relationship between food (POM) and mussel $\delta^{15} \mathrm{~N}$, but a negative relationship between nitrate $\delta^{15} \mathrm{~N}$ and consumers (mussels), which was strongly affected by site MC. Such negative relationships were previously found in systems with very high nitrogen concentrations (DIN $>40 \mu \mathrm{M}$ ) (Oczkowski et al., 2008), because in these systems primary producers can be choosy and will preferentially uptake lighter $\mathrm{NO}_{x}$, leading to a higher fractionation at higher concentrations (Lake et al., 2001; Oczkowski et al., 2008). Therefore, the residual $\mathrm{NO}_{x}$ in those waters retains more ${ }^{15} \mathrm{~N}$-enriched material, leading to a positive relation- 
ship between nitrogen concentration and nitrate $\delta^{15} \mathrm{~N}$, while consumers which incorporate primary producers will have a lighter signature. Because such fractionation is unlikely at TDIN concentrations below $1 \mu \mathrm{M}$ (Oczkowski et al., 2008), this mechanism is unlikely for most of our sites where mean TDIN concentration was $<1.5 \mu \mathrm{M}$. This is also supported by the lack of relationship between mussel $\delta^{15} \mathrm{~N}$ and TDIN concentration when omitting MC. However, we cannot rule out that this process contributed partially to the low mussel $\delta^{15} \mathrm{~N}$ values detected at MC, as TDIN concentrations were higher at this site with a mean of $3.6 \mu \mathrm{M}$. An alternative explanation would be that POM could originate upstream where nitrate might have had higher $\delta^{15} \mathrm{~N}$ values (not quantified in this study). Upon entering the estuary, POM mixes with estuarine POM, uncoupling the within-estuary $\delta^{15} \mathrm{~N}$ nitrate and POM $\delta^{15} \mathrm{~N}$ values. This could also explain the strong relationship between $\delta^{15} \mathrm{~N}$ in mussels and the distance from the estuary mouth found in our study. Such a strong relationship can be expected in estuaries with low pollution levels due to the aforementioned mixing, while little spatial variability in $\delta^{15} \mathrm{~N}$ values of primary consumers can be expected in heavily polluted estuaries due to the dominance of upstream POM, as was shown by Oczkowski et al. (2008).

The relationship between mussel $\delta^{15} \mathrm{~N}$ and TDIN concentration within the estuary was much stronger when omitting site $\mathrm{Cl}$ and not significant when omitting site MC. Site $\mathrm{Cl}$ was the shallowest site with a high density of macroalgae and seagrass. These benthic primary producers are known to incorporate nutrients from the groundwater and pore water (Pennifold and Davis, 2001). As pore water in the Swan River estuary contains a high concentration of ammonium (Linderfelt and Turner, 2001), this is taken up by the benthic primary producers, and, when recycled, nitrogen with a different $\delta^{15} \mathrm{~N}$ value is released into the water column. Therefore, nitrogen $\delta^{15} \mathrm{~N}$ in the water column at this site is likely to differ from that of all other sites, which could explain why mussel $\delta^{15} \mathrm{~N}$ values at $\mathrm{Cl}$ do not fit the general negative relationship. Due to constantly low nitrate concentration at this site, the stable isotope composition of nitrate could not be tested in our study. Site MC was closest to the ocean, was one of the deepest sites, and had a higher TDIN concentration compared to all other sites, which in turn did not show differences in TDIN concentrations between them. This emphasizes that the differences in mussel $\delta^{15} \mathrm{~N}$ between sites detected in our estuary might rather reflect site-specific nutrient cycling processes than nitrogen pollution itself.

Fluctuation of mussel $\delta^{15} \mathrm{~N}$ at each site over time was low compared to the differences between sites, indicating that observed differences between sites prevailed and were not obscured by time effects. This is important for assessing sitespecific processes and source inputs and highlights that mussels can be used as time-integrated sentinel organisms in urban systems. The limited temporal variation likely reflected the physiochemical state of the system during the study period; in our study, the estuary was dominated by marine in- fluences due to reduced river discharge. This might have further resulted in a dampening effect of possible fluctuations of the nitrate $\delta^{15} \mathrm{~N}$ value caused by changes in watershed input. Our results therefore highlight that while high seasonal variations of stable isotope signature in mussels can be connected to seasonal changes in watershed input and chemistry in large rivers (Fry and Allen, 2003), this is less pronounced in tidally influenced estuaries or during drier conditions with low freshwater input.

\section{Conclusion}

The findings of our study corroborate that stable isotope analysis is a valuable tool for identifying spatial variability of nutrient pollution and local processes in an urban, tidally influenced estuary. As such, stable isotope analysis of a model organism, such as the blue mussel, can deliver essential information for future decentralized water management practices that are focused on local process understanding. We propose to further investigate its use for assessing the pollution by co-occurring, non-nutrient pollutants, such as oils and heavy metals, which are entering waterbodies simultaneously with nutrients during stormwater events and which are critical in urban systems.

Based on nutrient concentrations and stable isotope analysis, our data provide detailed evidence that the lower Swan River estuary did not present a highly impacted urban estuary during our study. The nitrate stable isotope signature in the water suggested that the higher concentrations of nitrate at two sites (MC, SCC) were due to natural input of nitrate uncontaminated groundwater (Xue et al., 2009) rather than human pollution. The stable spatial differences in mussel $\delta^{15} \mathrm{~N}$ values over time highlight the value of this organism as a bioindicator of spatial water quality assessment. The negative trends between mussel $\delta^{15} \mathrm{~N}$ values and nitrate concentration or nitrate $\delta^{15} \mathrm{~N}$ values emphasize that mussels might not be good indicators for $\mathrm{NO}_{3}$ sources in systems with low pollution levels. Instead, the small differences in mussel stable isotope signatures might reflect differences in site-specific nutrient cycling caused by physicochemical conditions or biological factors rather than nitrogen pollution. This is important information for local management, but would have gone undetected at high pollution levels as the larger deviations of nitrogen stable isotope values would have made such small differences in mussel values invisible. In addition, we advocate future studies in similarly (low) polluted systems that include stable isotope analysis of other food web end-members and nutrients of the groundwater, to develop baselines of spatial natural isotopic variability in urban aquatic systems which will help identifying the importance of local biogeochemical processes for pollution control.

In conclusion, this work shows the value of using stable isotope analysis as an integrative tool to establish an understanding of local processes and pollution levels in aquatic 
systems. With an increasing importance of managing urban aquatic systems sustainably, our work presents an important proof-of-concept study in this context. In addition, we propose that it could help to define divisions in tidal estuaries based on natural characteristics and the human dimension that are meaningful for monitoring and management and for which reference conditions have to be identified (Ferreira et al., 2006).

Acknowledgements. This study was supported by a Research Development Award (2009) from The University of Western Australia to Elke S. Reichwaldt and by an Australian Research Council Linkage Project (LP0776571) and the Water Corporation of Western Australia. The authors would like to thank S. C. Sinang, H. Song, and L. X. Coggins for help in the field and in the laboratory; L. X. Coggins for editing an earlier version of the manuscript; and C. Harrod for valuable help during the preparation of the manuscript. The permit for sampling mussels was obtained from the Department of Environment and Conservation, Western Australia (Licence no. SF007464). Discharge data were courtesy of the Department of Water, Western Australia.

Edited by: A. Guadagnini

\section{References}

Almadavillela, P. C.: The effects of reduced salinity on the shell growth of small Mytilus Edulis, J. Mar. Biol. Assoc. UK, 64, 171-182, 1984.

Anderson, C. and Cabana, G.: $\delta^{15} \mathrm{~N}$ in riverine food webs: effects of $\mathrm{N}$ inputs from agricultural watersheds, Can. J. Fish. Aquat. Sci., 62, 333-340, 2005.

APHA: Standard methods for the examination of water and wastewater, 20th Edn., edited by: Greenberg, A. E., American Public Health Association, Washington, DC, 1998.

Atkins, R., Rose, T., Brown, R. S., and Robb, M.: The Microcystis cyanobacteria bloom in the Swan River - February 2000, Water Sci. Technol., 43, 107-114, 2001.

Atkins, R. P. and Klemm, V. V.: The effect of discharges, effluent and urbanisation on the Swan River, in: Swan River Estuary: Ecology and Management, edited by: John, J., Curtin University of Technology, Perth, Australia, Environmental Studies Group, Report no. 1, 296-313, 1987.

Beutler, M., Wiltshire, K. H., Meyer, B., Moldaenke, C., Lüring, C., Meyerhöfer, M., Hansen, U. P., and Dau, H.: A fluorometric method for the differentiation of algal populations in vivo and in situ, Photosynth. Res., 72, 39-53, 2002.

Brezonik, P. L. and Stadelmann, T. H.: Analysis and predictive models of stormwater runoff volumes, loads, and pollutant concentrations from watersheds in the Twin Cities metropolitan area, Minnesota, USA, Water Res., 36, 1743-1757, doi:10.1016/s00431354(01)00375-x, 2002.

Broderius, C.: Anthropogenically altered land and its effect on $\delta^{15} \mathrm{~N}$ values in periphyton on a fourth order stream in Utah's Cache Valley, Nat. Resour. Env. Iss., 18, 61-69, 2013.

Bureau of Meteorology: Climate statistics for Australian locations Monthly climate statistics, Australian Government, http://www. bom.gov.au/climate/averages/tables/cw_009034.shtml (last access: 3 March 2016), 2016.

Cabana, G. and Rasmussen, J. B.: Modeling food-chain structure and contaminant bioaccumulation using stable nitrogen isotopes, Nature, 372, 255-257, 1994.

Cabana, G. and Rasmussen, J. B.: Comparison of aquatic food chains using nitrogen isotopes, P. Natl. Acad. Sci. USA, 93, 10844-10847, 1996.

Cabana, G., Tremblay, A., Kalff, J., and Rasmussen, J. B.: Pelagic food-chain structure in Ontario Lakes - a determinant of mercury levels in Lake Trout (Salvelinus-Namaycush), Can. J. Fish. Aquat. Sci., 51, 381-389, 1994.

Carvalho, D. R., Castro, D., Callisto, M., Moreira, M. Z., and Pompeu, P. S.: Isotopic variation in five species of stream fishes under the influence of different land uses, J. Fish Biol., 87, 559-578, 10.1111/jfb.12734, 2015.

Chaves, M. M., Maroco, J. P., and Pereira, J. S.: Understanding plant responses to drought - from genes to the whole plant, Funct. Plant Biol., 30, 239-264, doi:10.1071/fp02076, 2003.

Choi, W. J., Han, G. H., Lee, S. M., Lee, G. T., Yoon, K. S., Choi, S. M., and Ro, H. M.: Impact of land-use types on nitrate concentration and $\delta^{15} \mathrm{~N}$ in unconfined groundwater in rural areas of Korea, Agr. Ecosyst. Environ., 120, 259-268, doi:10.1016/j.agee.2006.10.002, 2007.

Clay, A., Bradley, C., Gerrard, A. J., and Leng, M. J.: Using stable isotopes of water to infer wetland hydrological dynamics, Hydrol. Earth Syst. Sci., 8, 1164-1173, doi:10.5194/hess-8-11642004, 2004.

Costanzo, S. D., O’Donohue, M. J., Dennison, W. C., Loneragan, N. R., and Thomas, M.: A new approach for detecting and mapping sewage impacts, 42, 149-156, 2001.

Dähnke, K., Emeis, K., Johannsen, A., and Nagel, B.: Stable isotope composition and turnover of nitrate in the German Bight, Mar. Ecol.-Prog. Ser., 408, 7-U26, doi:10.3354/Meps08558, 2010.

Day, J. W. J., Hall, C. A. S., Kemp, W. M., and Yanez-Arancibia, A.: Estuarine chemistry, in: Estuarine Ecology, edited by: Day, J. W. J., Hall, C. A. S., Kemp, W. M., and Yanez-Arancibia, A., John Wiley \& Sons, New York, 1989.

Department of Water: Macrophytes and macroalgae in the SwanCanning Estuary (Volume 20), Department of Water, Perth, Australia, Perth, Australia, 2010.

Department of Water: River monitoring stations, Government of Western Australia, available at: http://kumina.water.wa.gov.au/ waterinformation/telem/stage.cfm (last access: 4 March 2016), 2016.

Dudley, B. D. and Shima, J. S.: Algal and invertebrate bioindicators detect sewage effluent along the coast of Titahi Bay, Wellington, New Zealand, New Zeal. J. Mar. Fresh., 44, 39-51, doi:10.1080/00288331003641687, 2010.

Durka, W., Schulze, E. D., Gebauer, G., and Voerkelius, S.: Effects of forest decline on uptake and leaching of deposited nitrate determined from ${ }^{15} \mathrm{~N}$ and ${ }^{18} \mathrm{O}$ measurements, Nature, 372, 765767, doi:10.1038/372765a0, 1994.

Fang, Y. T., Koba, K., Wang, X. M., Wen, D. Z., Li, J., Takebayashi, Y., Liu, X. Y., and Yoh, M.: Anthropogenic imprints on nitrogen and oxygen isotopic composition of precipitation nitrate in a nitrogen-polluted city in southern China, Atmos. Chem. Phys., 11, 1313-1325, doi:10.5194/acp-11-1313-2011, 2011. 
Ferreira, J. G., Nobre, A. M., Sirnas, T. C., Silva, M. C., Newton, A., Bricker, S. B., Wolff, W. J., Stacey, P. E., and Sequeira, A.: A methodology for defining homogeneous water bodies in estuaries - Application to the transitional systems of the EU Water Framework Directive, Estuar. Coast. Shelf S., 66, 468-482, doi:10.1016/j.ecss.2005.09.016, 2006.

Fertig, B., Carruthers, T. J. B., Dennison, W. C., Fertig, E. J., and Altabet, M. A.: Eastern oyster (Crassostrea virginica) $\operatorname{delta}(15) \mathrm{N}$ as a bioindicator of nitrogen sources: Observations and modeling, Mar. Pollut. Bull., 60, 1288-1298, doi:10.1016/j.marpolbul.2010.03.013, 2010.

Fry, B. and Allen, Y. C.: Stable isotopes in zebra mussels as bioindicators of river-watershed linkages, River Res. Appl., 19, 683696, 2003.

Fry, B., Rogers, K., Barry, B., Barr, N., and Dudley, B.: Eutrophication indicators in the Hutt River Estuary, New Zeal. J. Mar. Fresh., 45, 665-677, doi:10.1080/00288330.2011.578652, 2011.

Fukumori, K., Oi, M., Doi, H., Takahashi, D., Okuda, N., Miller, T. W., Kuwae, M., Miyasaka, H., Genkai-Kato, M., Koizumi, Y., Omori, K., and Takeoka, H.: Bivalve tissue as a carbon and nitrogen isotope baseline indicator in coastal ecosystems, Estuar. Coast. Shelf'S., 79, 45-50, 2008.

Geider, R. J., and La Roche, J.: Redfield revisited: variability of $\mathrm{C}: \mathrm{N}: \mathrm{P}$ in marine microalgae and its biochemical basis, Eur. J. Phycol., 37, 1-17, doi:10.1017/s0967026201003456, 2002.

Ghadouani, A. and Smith, R. E. H.: Phytoplankton distribution in Lake Erie as assessed by a new in situ spectrofluorometric technique, J. Great Lakes Res., 31, 154-167, 2005.

Gustafson, L., Showers, W., Kwak, T., Levine, J., and Stoskopf, M.: Temporal and spatial variability in stable isotope compositions of a freshwater mussel: implications for biomonitoring and ecological studies, Oecologia, 152, 140-150, 2007.

Hamilton, D. P.: Record summer rainfall induced first recorded major cyanobacterial bloom in the Swan River, The Environmental Engineer, 1, 25 pp., 2000.

Harrington, R. R., Kennedy, B. P., Chamberlain, C. P., Blum, J. D., and Folt, C. L.: ${ }^{15} \mathrm{~N}$ enrichment in agricultural catchments: field patterns and applications to tracking Atlantic salmon (Salmo salar), Chem. Geol., 147, 281-294, doi:10.1016/S00092541(98)00018-7, 1998.

Heathwaite, A. L.: Multiple stressors on water availability at global to catchment scales: understanding human impact on nutrient cycles to protect water quality and water availability in the long term, Freshwater Biol., 55, 241-257, 2010.

Heaton, T. H. E.: Isotopic studies of nitrogen pollution in the hydrosphere and atmosphere: A review, Chem. Geol., 59, 87-102, 1986.

Hobbs, R. J., Higgs, E., Hall, C. M., Bridgewater, P., Chapin, F. S., Ellis, E. C., Ewel, J. J., Hallett, L. M., Harris, J., Hulvey, K. B., Jackson, S. T., Kennedy, P. L., Kueffer, C., Lach, L., Lantz, T. C., Lugo, A. E., Mascaro, J., Murphy, S. D., Nelson, C. R., Perring, M. P., Richardson, D. M., Seastedt, T. R., Standish, R. J., Starzomski, B. M., Suding, K. N., Tognetti, P. M., Yakob, L., and Yung, L.: Managing the whole landscape: historical, hybrid, and novel ecosystems, Front. Ecol. Environ., 12, 557-564, doi:10.1890/130300, 2014.

Kellman, L. M.: A study of tile drain nitrate $-\delta^{15} \mathrm{~N}$ values as a tool for assessing nitrate sources in an agricultural region, Nutr.
Cycl. Agroecosys., 71, 131-137, doi:10.1007/s10705-004-1925$0,2005$.

Kendall, C.: Tracing nitrogen sources and cycling in catchments, in: Isotope tracers in catchment hydrology, edited by: Kendall, C. and McDonnell, J. J., Elsevier Science B.V., Amsterdam, 1998.

Kooistra, L., Leuven, R. S. E. W., Nienhuis, P. H., Wehrens, R., and Buydens, L. M. C.: A procedure for incorporating spatial variability in ecological risk assessment of Dutch River floodplains, Environ. Manage., 28, 359-373, doi:10.1007/S0026702433, 2001.

Lahr, J. and Kooistra, L.: Environmental risk mapping of pollutants: State of the art and communication aspects, Sci. Total Environ., 408, 3899-3907, doi:10.1016/j.scitotenv.2009.10.045, 2010.

Lake, J. L., McKinney, R. A., Osterman, F. A., Pruell, R. J., Kiddon, J., Ryba, S. A., and Libby, A. D.: Stable nitrogen isotopes as indicators of anthropogenic activities in small freshwater systems, Can. J. Fish. Aquat. Sci., 58, 870-878, 2001.

Lancaster, J. and Waldron, S.: Stable isotope values of lotic invertebrates: Sources of variation, experimental design, and statistical interpretation, Limnol. Oceanogr., 46, 723-730, 2001.

Linderfelt, W. R. and Turner, J. V.: Interaction between shallow groundwater, saline surface water and nutrient discharge in a seasonal estuary: the Swan-Canning system, Hydrol. Process., 15, 2631-2653, 2001.

Luedeking, A. and Koehler, A.: Regulation of expression of multixenobiotic resistance (MXR) genes by environmental factors in the blue mussel Mytilus edulis, Aquat. Toxicol., 69, 1-10, 2004.

Lutz, S. R., van Meerveld, H. J., Waterloo, M. J., Broers, H. P., and van Breukelen, B. M.: A model-based assessment of the potential use of compound-specific stable isotope analysis in river monitoring of diffuse pesticide pollution, Hydrol. Earth Syst. Sci., 17, 4505-4524, doi:10.5194/hess-17-4505-2013, 2013.

Mainwaring, K., Tillin, H., and Tyler-Walters, H.: Assessing the sensitivity of blue mussels (Mytilus edulis) to pressures associated with human activities, JNCC Report No 506, Joint Nature Conservation Committee, Petersborough, UK, 2014.

Makepeace, D. K., Smith, D. W., and Stanley, S. J.: Urban stormwater quality - summary of contaminant data, Crit. Rev. Env. Sci. Tec., 25, 93-139, 1995.

McClelland, J. W., Valiela, I., and Michener, R. H.: Nitrogen-stable isotope signatures in estuarine food webs: A record of increasing urbanization in coastal watersheds, Limnol. Oceanogr., 42, 930937, 1997.

McKinney, R. A., Lake, J. L., Charpentier, M. A., and Ryba, S.: Using mussel isotope ratios to assess anthropogenic nitrogen inputs to freshwater ecosystems, Environ. Monit. Assess., 74, 167-192, 2002.

Michener, R. and Lajtha, K.: Stable isotopes in ecology and environmental science, 2nd Edn., Blackwell Publishing Ldt., Malden, USA, 2007.

Oczkowski, A., Nixon, S., Henry, K., DiMilla, P., Pilson, M., Granger, S., Buckley, B., Thornber, C., McKinney, R., and Chaves, J.: Distribution and trophic importance of anthropogenic nitrogen in Narragansett Bay: An assessment using stable isotopes, Estuar. Coast, 31, 53-69, doi:10.1007/s12237-007-9029$0,2008$.

Pace, M. L., Cole, J. J., Carpenter, S. R., Kitchell, J. F., Hodgson, J. R., Van de Bogart, M. C., Bade, D. L., Kritzberg, E. S., and 
Bastviken, D.: Whole-lake carbon-13 additions reveal terrestrial support of aquatic food webs, Nature, 427, 240-243, 2004.

Pahl-Wostl, C.: Transitions towards adaptive management of water facing climate and global change, Water Resour. Manag., 21, 4962, doi:10.1007/s11269-006-9040-4, 2007.

Pennifold, M. and Davis, J.: Macrofauna and nutrient cycling in the Swan River Estuary, Western Australia: experimental results, Hydrol. Process., 15, 2537-2553, 2001.

Peters, N. E. and Donohue, R.: Nutrient transport to the SwanCanning Estuary, Western Australia, Hydrol. Process., 15, 25552577, 2001.

Phillips, D. J. H.: Common mussel Mytilus edulis as and indicator of pollution by zinc, cadmium, lead and copper. 1. Effects of environmental variables on uptake of metals, Mar. Biol., 38, 59-69, 1976.

Pickett, S. T. A., Cadenasso, M. L., Grove, J. M., Boone, C. G., Groffman, P. M., Irwin, E., Kaushal, S. S., Marshall, V., McGrath, B. P., Nilon, C. H., Pouyat, R. V., Szlavecz, K., Troy, A., and Warren, P.: Urban ecological systems: Scientific foundations and a decade of progress, J. Environ. Manage., 92, 331362, doi:10.1016/j.jenvman.2010.08.022, 2011.

Post, D. M.: Using stable isotopes to estimate trophic position: Models, methods, and assumptions, Ecology, 83, 703-718, 2002.

Raikow, D. F. and Hamilton, S. K.: Bivalve diets in a midwestern U.S. stream: A stable isotope enrichment study, Limnol. Oceanogr., 46, 514-522, 2001.

Redfield, A. C.: The biological control of chemical factors in the environment, Am. Sci., 46, 205-221, 1958.

Robinson, D.: $\delta 15 \mathrm{~N}$ as an integrator of the nitrogen cycle, Trends Ecol. Evol., 16, 153-162, doi:10.1016/s0169-5347(00)02098-x, 2001.

Rodgers, P., Soulsby, C., Waldron, S., and Tetzlaff, D.: Using stable isotope tracers to assess hydrological flow paths, residence times and landscape influences in a nested mesoscale catchment, Hydrol. Earth Syst. Sci., 9, 139-155, doi:10.5194/hess-9-139-2005, 2005.

Scheffer, M., Carpenter, S., Foley, J. A., Folke, C., and Walker, B.: Catastrophic shifts in ecosystems, Nature, 413, 591-596, 2001.

Sigman, D. M., Casciotti, K. L., Andreani, M., Barford, C., Galanter, M., and Bohlke, J. K.: A bacterial method for the nitrogen isotopic analysis of nitrate in seawater and freshwater, Anal. Chem., 73, 4145-4153, 2001.

Sikdar, P. K. and Sahu, P.: Understanding wetland sub-surface hydrology using geologic and isotopic signatures, Hydrol. Earth Syst. Sci., 13, 1313-1323, doi:10.5194/hess-13-13132009, 2009.

Sokal, R. R. and Rohlf, F. J.: Biometry: The principles and practices of statistics in biological research, 3rd Edn., W. H. Freeman, New York, 1995.

Stephens, R. and Imberger, J.: Dynamics of the Swan River estuary: The seasonal variability, Mar. Freshwater Res., 47, 517-529, 1996.
Stephens, R. and Imberger, J.: Intertidal motions within deep basin of Swan River estuary, J. Hydraul. Eng.-ASCE, 123, 863-873, 1997.

Sugimoto, R., Kasai, A., Miyajima, T., and Fujita, K.: Controlling factors of seasonal variation in the nitrogen isotope ratio of nitrate in a eutrophic coastal environment, Estuar. Coast. Shelf S., 85, 231-240, 2009.

Thompson, R. J. and Bayne, B. L.: Some relationships between growth, metabolism and food in mussel Mytilus edulis, Mar. Biol., 27, 317-326, 1974.

United Nations: World Economic and Social Survey 2013 - Sustainable Development Challenges, New York, USA, 2013.

van de Meene, S. J., Brown, R. R., and Farrelly, M. A.: Towards understanding governance for sustainable urban water management, Global Environ. Chang., 21, 1117-1127, doi:10.1016/j.gloenvcha.2011.04.003, 2011.

Volkmann, T. H. M. and Weiler, M.: Continual in situ monitoring of pore water stable isotopes in the subsurface, Hydrol. Earth Syst. Sci., 18, 1819-1833, doi:10.5194/hess-18-1819-2014, 2014.

Wang, Y., Yu, X., Zhang, L., and Lei, G.: Seasonal variability in baseline delta $\mathrm{N}-15$ and usage as a nutrient indicator in Lake Poyang, China, J. Freshwater Ecol., 28, 365-373, doi:10.1080/02705060.2013.763296, 2013.

Wen, Z. R., Xie, P., and Xu, J.: Mussel isotope signature as indicator of nutrient pollution in a freshwater eutrophic lake: species, spatial, and seasonal variability, Environ. Monit. Assess., 163, 139-147, doi:10.1007/s10661-009-0823-y, 2010.

$\mathrm{Xu}$, J. and Zhang, M.: Primary consumers as bioindicator of nitrogen pollution in lake planktonic and benthic food webs, Ecol Indic., 14, 189-196, doi:10.1016/j.ecolind.2011.02.012, 2012.

Xue, D., Botte, J., De Baets, B., Accoe, F., Nestler, A., Taylor, P., Van Cleemput, O., Berglund, M., and Boeckx, P.: Present limitations and future prospects of stable isotope methods for nitrate source identification in surface- and groundwater, Water Res., 43, 1159-1170, doi:10.1016/j.watres.2008.12.048, 2009.

Yang, L., Song, X., Zhang, Y., Han, D., Zhang, B., and Long, D.: Characterizing interactions between surface water and groundwater in the Jialu River basin using major ion chemistry and stable isotopes, Hydrol. Earth Syst. Sci., 16, 4265-4277, doi:10.5194/hess-16-4265-2012, 2012.

Widdows, J., Fieth, P., and Worrall, C. M.: Relationships between seston, available food and feeding activity in the common mussel Mytilus edulis, Mar. Biol., 50, 195-207, 1979.

Zandee, D. I., Kluytmans, J. H., Zurburg, W., and Pieters, H.: Seasonal variations in biochemical composition of Mytilus edulis with reference to energy metabolism and gametogenesis, Neth. J. Sea Res., 14, 1-29, 1980. 